\title{
IBM HOME INDUSTRI JAMU TRADISIONAL MADURA UNTUK MENINGKATKAN DAYA SAING DI KABUPATEN PAMEKASAN
}

\author{
Zainol Arifin ${ }^{1)}$, Fitrah Yuliawati2), Syafrawi ${ }^{33}$, \\ 1)Dibiayai Dikti Nomor: 108/SP2H/PPM/DRPM, Tanggal 17 Pebruari 2016 \\ 2.3.4).Program Studi Agribisnis Universitas Islam Madura \\ Email: dr.zainolarifin@gmail.com
}

\begin{abstract}
ABSTRAK
Salah satu konsep kemajuan pendidikan tinggi di Indonesia adalah technopreneurship yang merupakan cikal bakal masuknya dunia kerja dan dunia industri, seiring masuknya pasar ekonomi asean Kegiatan Ipteks bagi Masyarakat (IbM) kami lakukan pada dua home industri di Kecamatan Pakong Kabupaten Pamekasan. Metode pelaksanaan terdiri dari tahap persiapan, tahap awal tahap pelaksanaan. Evaluasi dan hasil pelaksanaan IbM menunjukkan bahwa: 1) Secara umum anggota home industry Jamu tradisional "Pj Melati" dan anggota home industry jamu tradisional "Pj. Tongkat Sapu Jagad" mulai mengelola bagaimana cara meracik dan mencampur bahan jamu tradisional dapat menarik baik dari rasa maupun dari aroma sehingga kemasan tetap diminati masyarakat di Indonesia; 2) Sebagian besar Telah memahami dan menerapkan tugas dan tanggung jawab masing-masing sesuai job description; 3) menerapkan skedul terjadwal pengolahan secara sistematis dan terencana, baik pembuatan jamu mulai asam urat, sehat lelaki, maupun sehat perempuan yang terdiri dari bahan alami seperti Cikeling, Kapulaga, Manjakani, maupun Palasari. Untuk memenuhi permintaan pasar dan konsumen, khususnya para tengkulak dalam bentuk besar dilayani secara khusus. Teknologi pengemasan dengan menggunakan manual atau tangan-tangan terampil disesuaikan dengan keahlian dan kemahiran; 4) Telah memahami dan mulai menerapkan pencatatan transaksi keuangan setiap penjualan secara teratur dan secara periodic, yaitu pencatatan keuangan sederhana dengan periodesasi yaitu pencatatan keuangan sederhana dengan periode mingguan, bulanan untuk satu home industry jamu tradisional; 5) Anggota kelompok home industry "Pj Melati” dan" PJ Tongkat Sapu Jagad" sebagian besar menerapkan strategi pemasaran melalui iklan media cetak sampai dengan media elektronik atau di took-toko maupun swalayan dsekitar wilayah kota pamekasan; 6) Mulai menerpkan pengemasan dengan mencantumkan komposisi bahan-bahan (Ingridients) dan tanggal kadaluwarsa (expired date); 7) Sudah memiliki Surat Ijin Usaha Penerbitan (SIUP) dari Depkes bahkan sampai pada pengurusan BPOM (Badan Pengawasan Obat dan Makanan) sebagai bentuk legalisasi dan produk dan expailed tersebut.
\end{abstract}

\section{Kata Kunci : Pj. Melati, Pj. Tongkat Sapu Jagad, Daya Saing}

\section{PENDAHULUAN}

Manusia lahir di dunia ini adalah sebagai mahluk yang paling mulia, bila dibandingkan dengan mahluk lainnya. Namun demikian, manusia juga yang paling banyak tantangan hidupnya yang harus selalu dihadapinya.Bila kenyataan seperti ini kita tidak tanggulangi.niscaya tujuan hidup tidak akan tercapai.Tujuan hidup itu dapat tertcapai apabila keadaan jasmani dan rohani kita dalam keadaan sempurna. Sempurna yang dimaksud yaitu tidak mengalami suatu gangguan yang dapat berpengaruh terhadap diri kita, sehingga tugas sehari-hari dapat terlaksana dengan baik.

Produktivitas tanaman cabe jamu di Kabupaten Pamekasan pada tahun 2014-2015 mengalami peningkatan yang sangat tinggi, yang diakibatkan permintaan pasar (Dinas Perindustrian dan Perdagangan Kabupaten Pamekasan, 2014). Data Produktivitas tanaman cabe jamu.

Beberapa tahun terakhir ini, jamu tradisional mendapat perhatian sangat besar karena adanya fakta empiris serta bukti penelitian ilmiah yang menyatakan bahwa jamu tradional berkhasiat untuk mengobati beberapa penyakit.

Pemanfaatan jamu tradisional sebagai obat tradisional baik di dalam maupun di luar negeri sebenarnya sudah sejak ribuan tahun yang lalu., mengemukakan, pada tahun $100 \mathrm{SM}$ penduduk Asia Tenggara berimigrasi ke kepulauan Polinesia dan membawa pengaruh besar sebagai tanaman obat. Sejak saat itu di Madura dengan meracik berbagai jenis tanaman obat yang langka dan banyak diminati oleh berbagai kalangan masyarakat, baik untuk kesehatan wanita maupun laki-laki.

Di Indonesia sendiri tanaman obat-obatan sudah dimanfaatkan sejak jaman dahulu kala. Menurut silsilahnya bahwa tanaman obat merupakan tanaman asli dari Asia Tenggara, termasuk Indonesia dan Madura. tumbuh hampir diseluruh kepulauan di Indonesia, umumnya tumbuh liar di pantai laut, di pinggir hutan, ladang, pinggir jalan dan aliran air, serta pinggir kampung. Tanaman ini sengaja ditanam sebagai batas kepemilikan tanah dan untuk 
kebutuhan obat keluarga. Penggunaan tanaman dan obat-obatan sebagai obat di Indonesia tercatat dalam cerita pewayangan yang ditulis dalam pemerintahan raja-raja dan para wali yang ada di Madura. Bukti sejarah pemanfaatan jamu tradisonal pada masa itu dapat dilihat dari terdapatnya tanaman obat-obatan yang tumbuh di museum koleksi tanaman obat di keraton bekas kerajaan dan di mesjid-mesjid para sunan. Di Keraton Sumenep misalnya terdapat obatobatan yang umurnya diperkirakan sudah ratusan tahun. Dalam pengobatan tradisional, jamu tradisional digunakan untuk obat batuk, radang amandel, sariawan, tekanan darah tinggi, beri-beri, melancarkan kencing, radang ginjal, radang empedu, radang usus, sembelit, limpa, lever, kencing manis, cacingan, cacar air, sakit pinggang, sakit perut, masuk angin, dan kegemukan, melangsingkan wanita dan memperbuat laki-laki perkasa.

PJ Melati dan Tongkat Sapu Jagad adalah perusahan home industri yang bergerak $\mathrm{di}$ bidang pembuatan jamu tradisional, perusahaan ini telah memproduksi beberapa macam jenis jamu tradisional salah satunya adalah . Kelompok Home industri Jamu Mengkudu (PJ Melati \& Tongkat Sapu Jagad) memiliki anggota sebanyak 20 orang dan 12 orang, yang berasal dari dua desa yaitu 20 orang dari Desa Seddur , 12 orang dari Desa Klompang Timur. Kegiatan kelompok Home industri jamu tradisonal ini bertumpu pada kegiatan pengolahan seperti pemilahan bahan atau pengeringan bahan, pengolahan dan pemasaran hasil. Kelompok home industri jamu tradisional ini dibangun dari 2 desa yang saling bersebelahan. Anggota home industri PJ Melati \& Tongkat Sapu jagad berprofesi kesemuanya sebagai petani, kegiatan pembuatan jamu tradisional hanya sebagai pekerjaan sampingan untuk menupang ekonomi bagi keluarganya.

Rencana pola yang dipakai dalam program ini adalah berbasis kemitraan dan keberlanjutan sehingga akan menghasilkan program yang sesuai dengan harapan semua pihak. Adapun fase pola kesinambungan tersebut digambarkan seperti gambar di bawah ini:

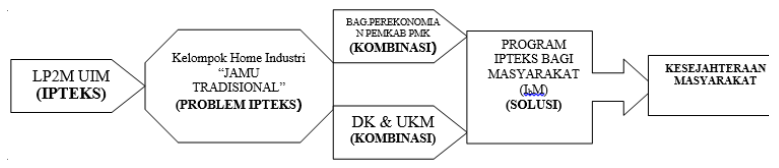

Gambar 1. Fase Kesinambungan Program IbM

Model diatas diharapkan menghasilkan kesinambungan dalam pemanfaatan produk iptek yang mampu di difungsikan oleh kelompok
Home industri jamu tradisonal yang nantinya akan dibantu oleh beberapa stakeholder yang berkepentingan (Dinas Kehutan dan Perkebunan,Bagian Perekonomian Setda Pemkab Pamekasan, Dinas Koperasi \& UMKM), sehingga akan mempercepat peningkatan perekonomian dan kesejahteraan masyarakat pertanian di Madura.

\section{TARGET DAN LUARAN}

Adapun target dan luaran dilaksanakannya kegiatan IbM Kelompok home industri PJ Melati dan Tongkat Sapu Jagad adalah:

1) Setiap anggota kelompok home industri PJ Melati \& Tongkat Sapu Jagad mampu mendeversifikasi produk jamu tradisional (local), sehingga nilai jual jamu tradisonal (nasional) bahkan kelaur negeri dan atau mancanegara meningkat. [PRODUK]

2) Meningkatnya kualitas SDM dan kemandirian dan Pengelolaan Kelompok home industri PJ Melati dan Tongkat Sapu Jagad. [MANAJEMEN]

3) Terciptanya produk-produk baru olahan jamu tradisional dan bermerk menjadi produk unggulan yang bernilai jual tinggi. [PRODUK]

4) Terciptanya media pemasaran melalui internet untuk produk kelompok home industry PJ Melati \& Tongkat Sapu Jagad. [PRODUK]

- www.melati.com

- www.talisapujagad.com

Setiap kelompok diberikan produk berupa web e-commerce untuk bisa memasarkan produk IbM mereka melalui media internet, dengan tujuan mempercepat promosi dan pemesanan. Kelompok yang dilatih pemanfaatan e-commerce adalah mereka yang masih usia produktif yang mampu dan mengerti cara atau teknik pengoperasian komputer.

5) Meningkatnya bahan baku tanaman obatobatan jamu tadisonal baik secara kualitas ataupun kuantitas. [PRODUK]

Hasil luaran diatas akan mampu memberikan dampak pada kelompok home industri PJ Melati \& Tongkat Sapu Jagad, diantaranya adalah:

1) Proses updating ipteks bagi masyarakat khususnya bagi kelompok home industri PJ Melati \& Tongkat Sapu Jagad.

2) Meningkatkan pengetahuan dan kepedulian kelompok home industri PJ Melati \& Tongkat Sapu Jagad terhadap masyarakat sekitarnya tentang dunia usaha dan manajemen keuangan mereka. 
3) Meningkatkan pengetahuan mereka dibidang pengolahan tanaman obat-obatan menjadi produk olahan jamu tradisional yang bernilai jual tinggi.

4) Meningkatkan kemampuan manajemen SDM beserta keuangan bagi kelompok sehingga mampu menjadikan kelompok home industri PJ Melati \& Tongkat Sapu Jagad yang sehat dan mandiri.

5) Meningkatkan kesejahteraan kelompok home industri PJ Melati \& Tongkat Sapu Jagad dan masyarakat sekitarnya.

6) Peningkatan kegiatan pengembangan ilmu, teknologi dan seni di perguruan tinggi.

\section{METODE PELAKSANAAN}

Berdasarkan beberapa hasil diskusi dan kajian tentang permasalahan diatas, maka ada beberapa solusi yang ditawarkan sebagai berikut:

1) Pelatihan Manajemen untuk home industri PJ Melati \& Tongkat Sapu Jagad:

a. Manajemen SDM dalam hal perencanaan, pengorganisasian, pemahaman dan pendefinisian terhadap kerja (job description) sehingga masing-masing divisi memahami tugas dan fungsinya serta dapat meningkatkan kinerja dari divisi. Selain itu, dalam hal perencanaan program kerja perlu diberikan pembinaan tentang pembuatan program kerja yang terjadwal (time scheduling) sehingga program kerja menjadi lebih terarah dan dapat meningkatkan kinerja daripada anggota kelompok.

b. Manajemen keuangan, dalam hal pembukuan atau pencatatan transaksi keuangan sehingga mereka dapat mengetahui berapa besarnya pemasukan dan pengeluaran setiap musimnya, dengan pembuatan jurnal sederhana untuk mencatat setiap transaksi keuangan, maka dapat membentuk arus kas serta melakukan analisis terhadap arus kas (Cash Flow Analysis) untuk setiap musimnya, sehingga dapat menjadi pedoman atau acuan bagi kelompok home industri PJ Melati \& Tongkat Sapu Jagad dalam hal perencanaan keuangan sehingga hutang atau pinjaman yang tidak terduga dapat diminimalisir.

2) Pelatihan Deverifikasi Produk jamu lokal menjadi jamu tradisional, untuk meningkatkan nilai jual jamu tradisional maka perlu dikembangkan beberapa pelatihan deversifikasi pengolahan diantaranya adalah: cara meracik, ektrak tanaman obat, minuman yang berkasiat siap saji, menyehatkan badan.

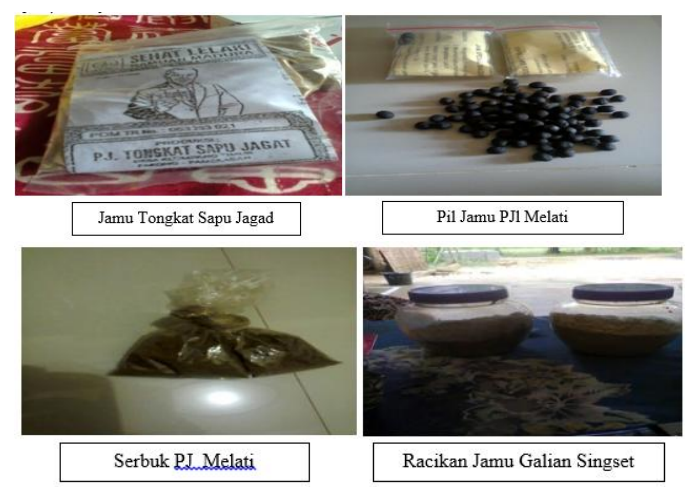

Gambar 2. Pelatihan Produk Pembuatan Jamu

Target luaran adalah HOME INDUSTRI JAMU TRADISONAL menjadi produk yang mempunyai nilai jual tinggi, hal ini harus dimiliki oleh kelompok home industri jamu tradisonal yang sampai saat ini mereka hanya mampu mengolah tanaman onat-obatan menjadi jamu dan pil serta jus. selain itu mereka belum mempunyai keahlian untuk mengolah jamu tradisional bernilai jual tinggi.

Tabel 1. Rencana Bahan Untuk Pembuatan Jamu Tradisional

\begin{tabular}{|c|c|c|}
\hline No & $\begin{array}{c}\text { Materi } \\
\text { Pelatihan }\end{array}$ & Bahan - Bahan \\
\hline 1. & $\begin{array}{l}\text { Serbuk Jamu } \\
\text { Tradisioanl }\end{array}$ & $\begin{array}{l}\text { - } \text { Cikeling ( } 1 / 4 \mathrm{~kg}) \text {, dihaluskan } \\
\text { - } 1 / 2 \text { ons Kayu rapet } \\
\text { - } 1 / 2 \text { Ons Kapulaga } \\
\text { - } 1 / 4 \text { Manjakani } \\
\text { - } 1 \text { ons Palasari } \\
\text { - } 1 / 4 \text { Peka' } \\
\text { - } 1 \text { ons Kemukus } \\
\text { - } 1 / 4 \text { Masaji }\end{array}$ \\
\hline 2. & $\begin{array}{c}\text { Pil } \\
\text { Tradisional }\end{array}$ & $\begin{array}{l}\text { - } \text { Cikeling ( } 1 / 4 \mathrm{~kg}) \text {, dihaluskan } \\
\text { - } 1 / 2 \text { ons Kayu rapet } \\
\text { - } 1 / 2 \text { Ons Kapulaga } \\
\text { - } 1 / 4 \text { Manjakani } \\
\text { - } 1 \text { ons Palasari } \\
\text { - } 1 / 4 \text { Peka' } \\
\text { - } 1 \text { ons Kemukus } \\
\text { - } 1 / 4 \text { Masaji }\end{array}$ \\
\hline 3. & $\begin{array}{l}\text { Jus Jamu } \\
\text { Tradisional }\end{array}$ & $\begin{array}{l}\text { - } \quad \text { Cikeling }(1 / 4 \mathrm{~kg}) \text {, dihaluskan } \\
\text { - } 1 / 2 \text { ons Kayu rapet } \\
\text { - } 1 / 2 \text { Ons Kapulaga } \\
\text { - } 1 / 4 \text { Manjakani } \\
\text { - } 1 \text { ons Palasari } \\
\text { - } 1 / 4 \text { Peka' } \\
\text { - } 1 \text { ons Kemukus } \\
\text { - } \quad 1 / 4 \text { Masaji }\end{array}$ \\
\hline
\end{tabular}

3) Pelatihan teknologi budidaya tanaman obatobatan sesuai dengan standar good 
agricultural practice (GAP). Untuk meningkatkan kualitas dan kuantitas bahan baku yang dipakai sebagai jamu tradisonal.

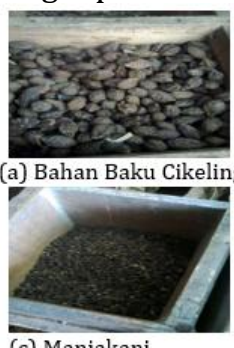

(c) Manjakani

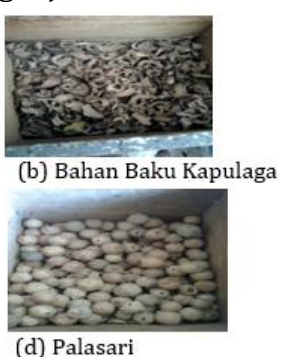

(d) Palasari

Gambar 3. Bahan-bahan Jamu Tradisional Madura

Pelatihan ini akan dilakukan selama 1 minggu untuk setiap mitra. Dengan menyesuaikan materi pelatihan sesuai dengan potensi sumber daya alamnya dan kondisi masyarakat, tabel kegiatan diatas hanya sebagai acuan awal untuk penerapan ipteks bagi masyarakat.

Desa Seddur dan Klompang Timur mempunyai potensi hasil pertanian yang melimpah pada hampir setiap bulan tertentu yang menyebabkan mudah untuk memperoleh bahan baku obat-obatan keluarga.

4) Pelatihan pembuatan pemasaran di internet. Kedepan home industri PJ Melati \& Tongkat Sapu Jagad akan mampu mempromosikan dan menjual produk mereka tanpa dibatasi oleh waktu dan tempat, sehingga akan mempercepat perkembangan usaha dan meningkatkan kesejahteraan home industri PJ Melati \& Tongkat Sapu Jagad. Media promosi menggunakan internet saat ini sangat relevan dimana masyarakat sudah terbiasa mencari sesuatu kebutuhan pribadi, perusahaan atau instansi menggunakan media internet. Pelatihan merupakan bagian yang penting dalam $\mathrm{I}_{\mathrm{b}} \mathrm{M}$ bagi home industri PJ Melati \& Tongkat Sapu Jagad. Kegiatan ini merupakan ajang kegiatan transfer teknologi dan atau pengetahuan dari narasumber kepada peserta pelatihan. Pelatihan dapat dilakukan di dalam kelas ataupun di lapangan dengan cara belajar sambil bekerja (learning by doing). Dengan fasilitas tim peneliti, monev secara partisipatif dimaksudkan untuk melihat pelaksanaan kegiatan yang dapat memberikan manfaat bagi sasaran. Pelaksanaan IbM ini melibatkan semua pemangku kepentingan yang berperan sebagai sumber teknologi, sekaligus penyandang dana. Selanjutnya pendampingan mempunyai peran sangat penting bagi berhasilnya pelatihan yang dilakukan. Pendampingan dilaksanakan oleh tim pelaksana dibantu oleh beberapa orang dosen dan mahasiswa

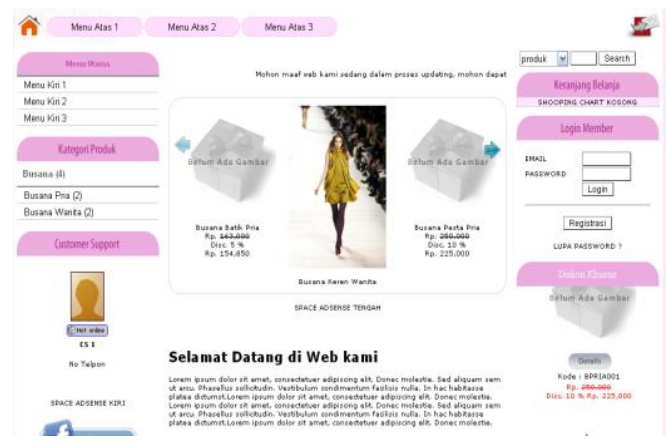

Gambar 4. Model Perancangan e-commerce

Dengan semakin berkembangnya trend pemanfaatan teknologi informasi, maka alangkah baiknya apabila hasil home industry jamu tradisional sudah saatnya melakukan trend itu. Tim pelaksana IbM akan membuatkan setiap mitra web e-commerce untuk mempromosikan produk-produk mereka, setelah itu akan dilakukan pelatihan kepada admin yang nantinya akan mengelola web tersebut.

\section{HASIL DAN PEMBAHASAN}

Sesuai dengan target dan luaran program IbM telah banyak yang sudah dicapai bagi Home Industri Jamu Tradisional di Kecamatan Pakong Kabupaten Pamekasan, sebagai berikut:

Tabel 2. Pencapaian Hasil IbM

\begin{tabular}{|c|c|c|c|}
\hline No & $\begin{array}{c}\text { Nama } \\
\text { Kegiatan }\end{array}$ & Target & Capaian \\
\hline 1. & $\begin{array}{l}\text { Pelatihan } \\
\text { Deversifikas } \\
\text { i Produk } \\
\text { Jamu } \\
\text { Tradisional }\end{array}$ & $\begin{array}{l}\text { - Serbuk } \\
\text { Jamu } \\
\text { Tradisioanl } \\
\text { - Pil } \\
\text { Tradisional } \\
\text { - Jus Jamu } \\
\text { Tradisional }\end{array}$ & $\begin{array}{l}\text { - Capaian target } \\
\text { dari pelatihan } \\
\text { ini mencapai } \\
90 \% \text {, hal ini } \\
\text { dilihat dari } \\
\text { produk, yang } \\
\text { dihasilkan } \\
\text { setelah } \\
\text { pelatihan } \\
\text { sangat } \\
\text { bervariasi } \\
\text { sekali diantara } \\
2 \text { kelompok } \\
\text { tersebu;. } \\
\text { Tidak } \\
\text { tercapainya } \\
\text { kepada target } \\
\text { disebabkan } \\
\text { beberapa } \\
\text { faktor, } \\
\text { terutama } \\
\text { adalah } \\
\text { keterbatasan }\end{array}$ \\
\hline
\end{tabular}




\begin{tabular}{|c|c|c|c|}
\hline & & & $\begin{array}{l}\text { waktu yang } \\
\text { dimiliki untuk } \\
\text { pelatihan; } \\
\text { - } \text { Solusi untuk } \\
\text { mengatasi hal } \\
\text { tersebut tim } \\
\text { IbM telah } \\
\text { melakukan } \\
\text { jadwal } \\
\end{array}$ \\
\hline 2 & $\begin{array}{l}\text { Pelatihan } \\
\text { Manajemen } \\
\text { SDM dan } \\
\text { Keuangan }\end{array}$ & $\begin{array}{l}\text { - Memhami } \\
\text { cara disiplin, } \\
\text { inovasi dan } \\
\text { kreatif } \\
\text { - Memahami } \\
\text { akuntansi } \\
\text { dan } \\
\text { pembukuan } \\
\text { sederhana } \\
\text { untuk } \\
\text { menjalankan } \\
\text { usaha. }\end{array}$ & $\begin{array}{l}\text { - Capaian target } \\
\text { dari pelatihan ini } \\
\text { mencapai 85\%, } \\
\text { hal ini dilihat } \\
\text { dari tingkat } \\
\text { pendidikan dan } \\
\text { keseriusan } \\
\text { diantara } 2 \\
\text { kelompok } \\
\text { tersebut; } \\
\text { - Tidak } \\
\text { tercapainya } \\
\text { kepada target } \\
\text { disebabkan } \\
\text { beberapa faktor, } \\
\text { terutama adalah } \\
\text { tingkat } \\
\text { pendidikan yang } \\
\text { rendah dan } \\
\text { cenderung malas } \\
\text { untuk berfikir } \\
\text { dan } \\
\text { mendengarkan; } \\
\text { - Solusi untuk } \\
\text { mengatasi hal } \\
\text { tersebut tim IbM } \\
\text { telah melakukan } \\
\text { jadwal } \\
\text { konsultasi dan } \\
\text { pendampingan } \\
\text { setiap hari } \\
\text { minggu dengan } \\
\text { para pakar. }\end{array}$ \\
\hline 3. & $\begin{array}{l}\text { Pembuatan } \\
\text { Web e- } \\
\text { commerce } \\
\text { dan } \\
\text { Pelatihan }\end{array}$ & $\begin{array}{l}\text { - Terwujudny } \\
\text { a e- } \\
\text { commerce } \\
\text { untuk } 2 \\
\text { kelompok; } \\
\text { - Mampu } \\
\text { mengoperasi } \\
\text { kan dan } \\
\text { Memperbaik } \\
\text { i Web jika } \\
\text { ada } \\
\text { kesalahan. }\end{array}$ & $\begin{array}{l}\text { - Capaian target } \\
\text { dari pelatihan } \\
\text { ini mencapai } \\
75 \% \text {, hal ini } \\
\text { dilihat dari } \\
\text { kemampuan } \\
\text { administrasi } \\
\text { dari } 2 \\
\text { kelompok } \\
\text { tersebut dalam } \\
\text { mengelola web; } \\
\text { Tidak } \\
\text { tercapainya } \\
\text { kepada target } \\
\text { 100\%, } \\
\text { disebabkan } \\
\text { beberapa } \\
\text { faktor, } \\
\text { terutama } \\
\text { adalah } \\
\text { keterampilan } \\
\text { dan } \\
\text { pengetahuan } \\
\text { mereka yang } \\
\text { terbatas; } \\
\text { Solusi untuk } \\
\text { mengatasi hal } \\
\text { tersebut tim } \\
\text { IbM telah }\end{array}$ \\
\hline
\end{tabular}

\begin{tabular}{|c|c|c|c|}
\hline & & & $\begin{array}{l}\text { melakukan } \\
\text { jadwal } \\
\text { konsultasi dan } \\
\text { pendampingan } \\
\text { setiap } \\
\text { hariminggu } \\
\text { dan libur } \\
\text { dengan para } \\
\text { pakar. } \\
\\
\\
\text { konsultasi dan } \\
\text { pendampingan } \\
\text { setiap hari } \\
\text { minggu dengan } \\
\text { para pakar. }\end{array}$ \\
\hline 4. & $\begin{array}{l}\text { Pelatihan } \\
\text { Meracik } \\
\text { Jamu } \\
\text { Tradisional }\end{array}$ & $\begin{array}{l}\text { - Mendesain } \\
\text { rasa dan } \\
\text { aroma } \\
\text { - Mampu } \\
\text { membuat } \\
\text { jamu lebih } \\
\text { memiliki } \\
\text { daya tarik }\end{array}$ & $\begin{array}{l}\text { - Capaian target } \\
\text { dari pelatihan } \\
\text { ini mencapai } \\
\text { 98\%, hal ini } \\
\text { dilihat dari } \\
\text { produk yang } \\
\text { dihasilkan } \\
\text { setelah } \\
\text { pelatihan } \\
\text { sangat bagus } \\
\text { sekali diantara } \\
2 \text { kelompok } \\
\text { dan yang } \\
\text { dipasarkan } \\
\end{array}$ \\
\hline 5. & $\begin{array}{l}\text { Analisa dan } \\
\text { Pembuatan } \\
\text { artikel } \\
\text { ilmiah } \\
\text { untuk ikut } \\
\text { seminar } \\
\text { Nasional }\end{array}$ & $\begin{array}{l}\text { - Ikut Seminar } \\
\text { Nasional } \\
\text { pada Tahun } \\
2016 \\
\text { - Jurnal } \\
\text { Internasiona } \\
\text { l Bidang } \\
\text { Humaniora }\end{array}$ & $\begin{array}{l}\text { - Capaian target } \\
\text { mencapai } 30 \% \text {, } \\
\text { hal ini belum } \\
\text { terlaksana } \\
\text { semua karena } \\
\text { proses analisa } \\
\text { dampak IbM } \\
\text { terhadap } \\
\text { perilaku dan } \\
\text { Perekonomian } \\
\text { masyarakat } \\
\text { petani belum } \\
\text { selesai; } \\
\text { Solusi untuk } \\
\text { mengatasi hal } \\
\text { tersebut tim } \\
\text { IbM telah } \\
\text { menganalisa } \\
\text { dan mencoba } \\
\text { menyusun } \\
\text { menjadi karya } \\
\text { ilmiah baik } \\
\text { Nasional dan } \\
\text { Internasional. }\end{array}$ \\
\hline
\end{tabular}

Sehingga rata-rata hasil yang dicapai oleh tim IbM sebagai berikut :

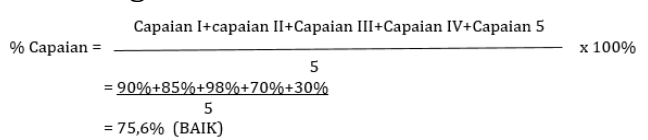

\section{Permasalahan 1}

Kelompok home industri Jamu "Pj Melati dan Tongkat sapu Jagad" masih begitu banyak kekurangan bahan yang perlu dilakukan oleh pihak pengusaha lokal. Seiring berjalannya 
waktu yang permintaan pasar, baik lokal maupun nasional. Bahwa jamu tradisional yang ada semakin kesulitan bahan baku. Maka untuk pengembangan bahan tersebut diperlukan import bahan dari luar yakni dari Kalimantan. Kan tetapi untuk meningkatkan rasa yang lebih baik.Kelompok Home Industri jamu Tradisonal sebagian besar menggunakan bahan lokal yang di Kabupaten Pamekasan.

Berdasarkan permasalahan di atas, maka kami melaksanakan kegiatan pengabdian melalui progran kegiatan IbM sebagai upaya memberikan solusi terhadap permasalahan diatas yaitu memberikan pelatihan ketrampilan diversifikasi pembuatan jamu tradisonal Madura. Ketrampilan yang diberkan akan memotivasi kelompok pembuat jamu dapat meningkatkan pendapatan keluarga segaligus mendapatkan nilai tambah bagi masyarakat yang ada disekitar pengembang kelompok home industri jamu tradisonal.Selain itu pula teknik memanam cabe jamu dapat disekitar lingkungan pertanian dapat meningkatkan penghasilan petani, dikarenakan pelaku usaha jamu tradisional sangat membutuhkan bahan baku tersebut.

Tabel 3.Umpan Balik (FEED BACK) Kegiatan Pengabdian Masyarakat Ipteks Bagi Masyarakat ( $\mathrm{I}_{\mathrm{b}} \mathrm{M}$ ) Kelompok Home Industri Jamu Tradisional Madura

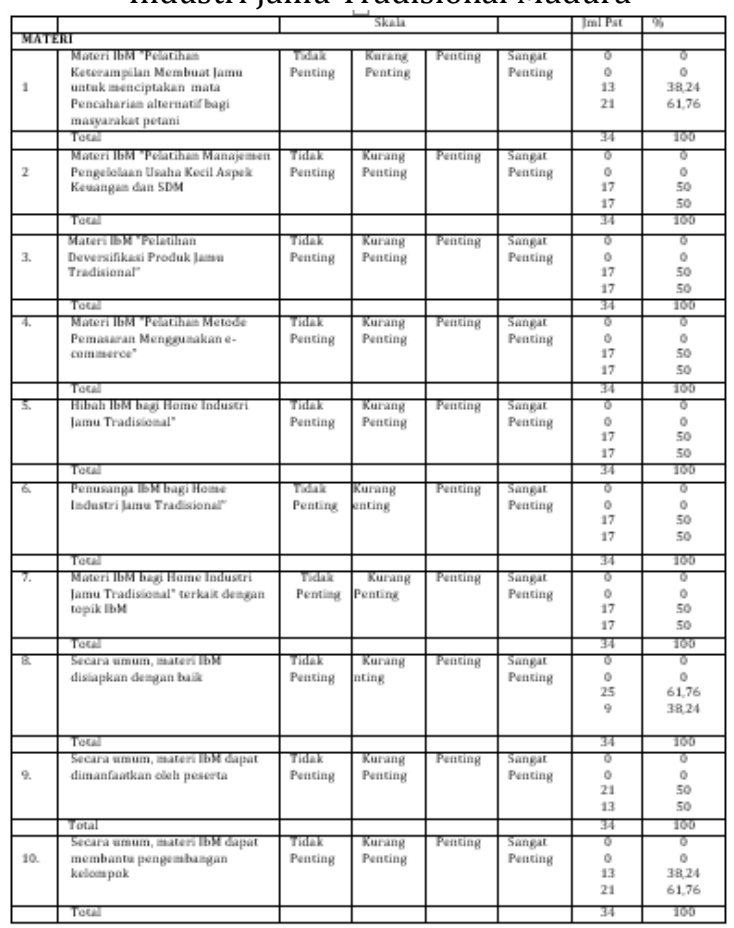

Disamping itu pula, pelatihan diversifikasi jamu tradisional Madura diharapkan masyarakat dapat meningkatkan ketrampilan dan keahlian. Mengingat selama ini cara meracik bahan-bahan tersebut masih tergantung pada kebiasaan masyarakat dan sifatnya turun temurun oleh nenek moyang.

Pelatihan diversifikasi jamu tradisional yang kami berikan disambut dengan antusias oleh kelompok PJ Melati dan PJ Tongkat Sapu Jagad. Hal ini dibuktikan dengan kehadiran mereka yang sangat aktif disertai rasa ingin tahu yang tinggi terutama oleh para anggota yang lain.

\section{Permasalahan 2}

Permasalahan yang dihadapi oleh kelompok home industri jamu tradisional " $\mathrm{Pj}$ Melati: dan "Pj Tongkat Sapu Jagad" yaitu struktir organisasi yang terdapat pada dua home industri sangatlah sederhana. Walaupun sudah ada beberapa divisi dan staf, tapi masih mengalami hambatan dan tumpang tindih antar pekerjaan. Mengingat kadang pekerjaan satu dikerjakan oleh staf yang lain artinya mengalami job/kerja ganda. Sehingga tidak maksimal. Akan tetapi di home industri jamu tersebut kadang ketua merangkap dalam pekerjaan yang lain, tetapi tetap dapat dikerjakan. Untuk itu, dalam dunia usaha dan dunia industri yang dilakukan oleh kegiatan kelompok ini masih rendahnya tingkat pendidikan (mansead) terutama cara berpikir tiap-tiap anggota.yang mana usaha tersebut dalam bekerja masih bersifat kebutuhan keluarga dan bersifat konvensioanl.

Berdasarkan uraian diatas, maka kami melakukan kegiatan pengabdian melalui program IbM yakni memberikan tambahan pendidikan melalui pelatihan dan manajemen sumberdaya manusia (Human Resources) untuk dapat membekali dan memotivasi kelompok dalam rangka mengembangkan karakter dan prinsip.

Pendidikan dan pelatihan manajemen sumberdaya manusia yang dimaksud rasa keingintahuan anggota kelompok home industri . Dengan tujuan parsitisipasi aktif dalam pelatihan tersebut. Hal ini jika kelompok home industri bertanya dalam arti umpanbalik maka nara sumber yang kita paparkan akan dapat terjaab dan diterima oleh peserta.dari jumlah peserta pelatihan dan manjemen sumberdaya manusia yang hadir yang sangat penting $60 \%$ sebanyak 16 orang. Dan $40 \%$ orang sebanyak peserta tang menyatakan penting terhadap materi.

Setelah dilaksanakannya pelatihan manajemen sumberdaya manusia, anggota home industri jamu tradisional mudah memahami dan menerapkan tugas dan tanggungjawab masing-masing sesuai dengan pembagian tugas sebagaimana susunan 
organisasi yang ada. Disamping itu, kinerja anggota kelompok home industri jamu tradisonal madura ini akan meningkat. Hal ini dketahui dengan tidak tumpahtindihnya pekerjaan baik fungsi maupun divisi.

Setiap kegiatan yang dilakukan divisi membuat rencana program kegiatan baik mingguan maupun bulanan sebagai bentuk tugas dan tanggungjawab menjadi lebih baikk dan terarah. Hal ini menunjukkan kualitas sumberdaya manusia ada peningkatan kualitas . Sebagai gambaran dokumentasi kegiatan pelatihan sumberdaya manusia. Dokumendokumen pelaksanaan kegiatan IbM pendidikan dan pelatihan manajemen sumberdaya manusia.

\section{Permasalahan 3}

Usaha pengembangan jamu tradisional Madura "Pj Melati dan Pj Tongkat Sapu Jagad" Dari proses manajemen produksi belum dilaksanakan secara terarah, terukur, dan sistematis. Alat produksi yang dipergunakan masih sangat sederhana sehingga dapat menyebankan produksi menurun, seperti yang terdapat pada Pj Tongkat sapu Jagad hanya memenuhi kebutuhan lingkungan sekitar yaitu antara 10-15 kg setiap minggunya. Atas dasar permintaan pasar terhadap produksi jamu tradisional maka pengembangan usaha jamu tradisional Madura sampai mengalami kekurangan stock.Berdasarkan temuan dilapangan jamu yang diproduksi kadang dipasarkan sampai diluar Madura yakni Malang dan Jember.

Berdasarkan permasalahan diatas, dapat kami laksanakan kegiatan pengabdian melalui program IbM yaikni memberikan pembinaan manajemen produksi dalam melakukan kegiatan yakni faktor-faktor produksi usaha pengembangan jamu tradisional Madura yang dapat meningkatkan hasil baik melalui kwalitas maupun kuantitas.disamping juga ada penambahan alat dan bahan terhadap pengelolaan jamu yang dapat memproses baik sortasi maupun distribusi terhadap produk jamu khusus jamu tradisional Madura.

Pembinaan manajemen produksi terhadap jamu tradisonal mendapat respon positif dari anggota kelompok home industri. Hal ini dapat dilihat pada tabel 5. Yakni sebanyak 15 orang atau sebesar $50 \%$ menilai sangat penting terhadap materi pelatihan manajemen produksi dan sebanyak 15 orang $50 \%$ menilai penting terhadap materi pelatihan dan pembinaan manajemen produksi, rasa percaya ddiri anggota kelompok home industri jamu tradisional sagat tinggi memlalui partisipasi aktif dalam kegiatan pelatihan dan feed bak yang dapat merespon.
Berikut dapat ditunjukkan dengan beberapa penanya dan pertanyaan yang dilakukan oleh kami selaku pelaksana program IbM.

Dalam melaksanakan kegiatan pembinaan terhadap manajemen produksi yaitu dua kelompok home industri jamu tradisional dapat diimplementasikan tata urutan jadwal kegiatan, pengolahan secara beurutan. Disamping itu pula dua home industri jamu tradisional mulai memanfaatkan teknologi kemasan produk sistem pengepresan secara otomatis agar dapat lebih cepat dan dipasarkan. Agar terhindar dari sistem pemalsuan terhadap hasil pembuatan jamu maka diperlukan kode rahasia yang terdapat didalam label pembuatan jamu.Terdapat macam dan jeis jamu yang dikemas ada jamu asam urat, jamu sehat lelaki, sehat perempuan, jamu montok payudara, jamu peluntur lemak, Jamu pelintiran rapet wangi, dan jamu galian singset.

Dengan adanya pembinaan manajemen produksi yang kami laksanakan kepada home industri jamu tradisional produksi produksi mengalami kualitas. Mengingat kelompok tersebut cara berfikir dan cara pengelolaan berubah. Disamping itu pula setelah adanya kegiatan IbM jamu tradisional mengalami perubahan bentuk baik tampilan sampul jamu, kualitas racikan jamu, dan pemilahan bahan yang akan dicampur, aroma dan rasa ada peningkatan.

Sebelum dilaksanakan ibM, omset home idustri masih kecil dengan rata-rata penjualan perbungkus Rp. 10.000,- dengan berubahnya desain dan tampilan perbungkus bisa mencapai harga perbungkusnya Rp. 25.000,- untuk ukuran $1 / 4 \mathrm{~kg}$.Untuk itu setelah pelaksanaan kegiatan IbM pembinaan manajemen produksi, terjadi kenaikan omset penjualan, karena selain omset penjualan sisa bahan jamu yang tersortir dapat dijual juga dengan cara dicampur bahan tersebut untuk bisa laku dipasaran. Yaitu dengan tidak mengurangi takaran dan bentuk warna dan aroma.Dokumentasi kegiatan pembinaan manajemen produksi.

\section{Permasalahan 4}

Pengelolaan keuangan usaha jamu tradisional Madura oleh dua kelompok"Pj Melati dan Pj Tongkat sapu Jagad" belum dilakukan secara teratur dan sistematis, kenyataan yang ada sistem keuangan masih sangat sederhana yakni belum memiliki pembukuan yang sesuai standart yang benar. Akan tetapi setelah diadakan pembinaan keuangan oleh tim IbM mengalami perubahan yaitu pembukuan tertib dilakukan baik pembukuan harian, mingguan mapun bulanan. 
Atas dasar permasalahan tersebut diatas, maka tim IbM melaksanakan kegoatan pengabdian yaitu pelatihan manajemen keuangan dalam bentuk pencatatan transaksi keuangan sampai dengan pembuatan laporan keuangan secara periodik.

Pelatihan manajemen keuangan yang kami lakukan mendapat respon positif dari kelompok home industri jamu tradisional. Hal ini dapat dilihat tabel yang ada yaitu sebanyak 16 orang atau $61,76 \%$ menilai8 sangat penting terhadap penyampaian materi pelatihan manajemen keuangan dan sisanya sebanyak 12 orang 28,24\% hanya menilai terhadap materi pelatihan manajemen keuangan. Dalam mengikuti pelatohan manajemen keuangan, rasa antusias yang tingi anggota kelompok home industri jamu tradisional melalui program partisipatif aktif mereka dalam forum pelatihan dan feed back yang cepat. Hal ini ditunjukkan dengan banyaknya pertanyaan dan diskusi intensif yang sering mereka lakukan dengan pihak tim IbM.

Hasil yang didapat setelah pelaksanaan kegiatan manajemen keuangan yakni anggota kelompok home industri jamu tradisional memahami dan mulai menerapkan sistem keuangan dengan pencatatan keuangan setiap transaksi dan secara periodik, yaitu transaksi pencatatan keuangan dengan periode harian, mingguan dan bulanan. Sehingga dapat diketahui transaksi keuangan mulai dari solvabilitas, Likuiditas, Rentabilitas melalui cash Flow nantinya.yang kemudian menjadi pedoman atau acuan bagi kelompok home industri jamu tradisional Madura yang telah mereka lakukan selama ini.

\section{Permasalahan 5}

Permasalahan yang dihadapi pada kelompok home industri jamu tradisonal adalah tingkat pemasaran yang agak lambat. Khusus yang terjadi pada Pj Tongkat Sapu jagad yang berada agak jauh dari pasar di kecamatan. Melalui sistem pemasaran yang dilakukan agak cepat setelah diadakan pelatihan internet baik yang dipasarkan secara sistem penjualan manual ditingkat pasar kecil, pasar kecamatan maupun dipasar tingkat Kabupaten.

Untuk meningkatkan nilai penjualan kami mengadakan pelatihan internet pada kelompok Home industri untuk melatih bagaimana caracara memasarkan lewat dunia maya (internet) untuk bisa laku cepat. Hasil yang dicapai ternyata cepat meningkat. Terutama dari wilayah luar kota selain di Madura. Biasanya dari Jakarta, Surabaya, Malang dan Bogor serta Bandung. Bahkan melalui lewat pesanan barang tersebut lewat pos pengiriman, tiki (titipan kilat) maupun lewat jasa-jasa kantor yang memiliki ijin.

Sedangkan harga untuk masing-masingss produk jamu tradisional madura yang telah dihasilkan dalam bentuk kemasan produk sebagai berikut:

Tabel 4. Produk Jamu Tradisional Madura

\begin{tabular}{|l|l|l|l|}
\hline No. & Produk & Kemasan & Harga/Kemasan \\
\hline 1. & Jamu Sehat lelaki & 0,5 gram & Rp. 25.000,- \\
\hline 2. & Jamu Sehat Perempuan & 0,5 gram & Rp. 25.000,- \\
\hline 3. & Jamu Galian Singset & 0,5 gram & Rp. 25.000,- \\
\hline 4. & Jamu Galian Rapet & 0,5 gram & Rp. 25.000,- \\
\hline 5. & Jamu Paka' Ro'om & 0,5 gram & Rp. 25.000,- \\
\hline 6. & Jamu Asam Urat & 0,5 gram & Rp. 25.000,- \\
\hline
\end{tabular}

Di samping itu, selama pelaksanaan program IbM kelompok home industri jamu tradisional madura sebagai mitra program Ibm memberikan umpanbalik berupa penilaian terhadap variabel materi, variabel pemateri, variabel ruangan/tempat yang diguanakan, dan variabel rekomendasi. Umpan balik diisi melalui kuisioner yang telah kami sebar selama pelaksanaan program IbM. Adapun umpan balik yang diberikan oleh kelompok home industri jamu tradisional madura sebagai mitra IbM merupakan bahan evaluasi terhadap pelaksanaan program IbM yang telah kami laksanakan. Sehingga kami dapat mengetahui sejauh mana pencapaian pelaksanaan program Ibm ini. Umpanbalik terhadap pelaksanaan program IbM dapat disajikan pada tabel 6, 8, 9 dan 10.

Pada tabel 10, dapat dilihat, berkaitan dengan materi-materi pelatihan yang diberikan selama pelaksanaan IbM, sebagian besar anggotamitra IbM yaitu sebanyak 20 orang atau sebesar 73,53\% menilai penting terhadap materi IbM yang terkait dengan topik IbM. Dan sisanya sebanyak 10 orang atau sebesar 23,67 menilai sangat penting terhadap materi IbM yang terkait dengan topik IbM.Hal ini terkait dengan kemandirian dan kualitas sumberdaya manusia yang meningkat baik jasa maupun produk.

Pada tabel 10 juga dapat dilihat bahwa sebagian besar anggota mitra IbM menilai penting terhadap penugasan program IbM ini yaitu sebanyak 21 orang atau sebesar $61,76 \%$ dan sisanya sebanyak 13 orang 38,24\% menilai sangat penting. Hal ini sesuai dengan kebutuhan dan permasalahan yang mitra hadapi, khususnya tentang program diversifikasi produk jamu tradisional Madura.

Selain terhadap materi-materi pelatihan selama pelaksanaan program IbM, untuk mengetahui capaian pelaksanaan program IbM, kami juga memperoleh umpanbalik terhadap 
pemateri dalam pelaksanaan program IbM disajikan pada tabel 5 .

Berdasarkan tabel 5. Dapat dilihat bahwa sebagian besar anggota mitra IbM yaitu sebanyak 23 orang atau sebesar $67,65 \%$ menilai jelas terhadap penyampaian materi oleh pemateri dan sisanya sebanyak 11 orang atau sebesar 32,35\% menilai sangat jelas. Disamping itu dari tabel 5. Juga dapat diketahui bahwa sebanyak 28 orang atau sebesar 82,35\% menilai pemateri telah memanfaatkan waktu sesuai dengan jadwal yang diberikan. Sedangkan sisanya sebanyak 6 orang atau sebesar 17,65\% menilai sangat setuju terhadap pemateri yang telah memanfaatkan waktu sesuai jadwal yang diberikan.

Tabel 5. Umpanbalik Terhadap Pemateri

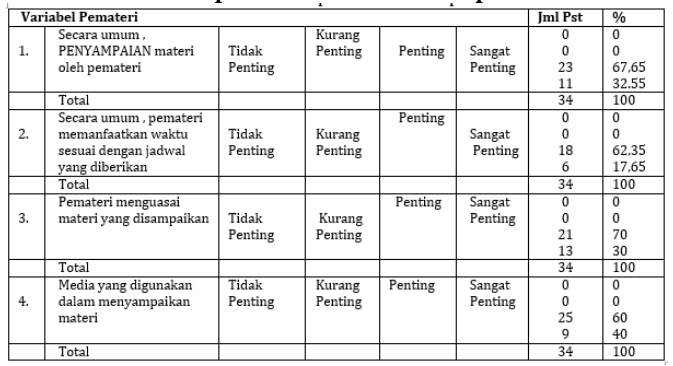

Pada tabel 5 juga menunjukkan bahwa sebanyak 20 orang anggota mitra IbM atau sebesar $70 \%$ menilai setuju pemateri menguasai materi yang dsampaikan dan sisanya sebanyak 12 orang atau sebesar $30 \%$ sangat setuju terhadap pemateri yang menguasai materi yang disampaikan. Sedangkan terhadap media yang digunakan dalam menyampaikan materi, sebanyak 20 orang atau sebanyak $60 \%$ menilai bahwa media yang digunakan baik dan sisanya sebanyak 7 orang atau sebesar $40 \%$ menilai bahwa media yang digunakan sangat baik.

Tabel 6. Umpan balik terhadap ruangan dan tempat yang digunakan dapat dilihat pada tabel berikut:

\begin{tabular}{|c|c|c|c|c|c|c|}
\hline Variabel Umpan Balik & \multicolumn{4}{|c|}{ Skala } & Jmlh & $\%$ \\
\hline $\begin{array}{l}\text { Kenyamanan ruangan } \\
\text { yang digunakan }\end{array}$ & $\begin{array}{l}\text { Tidak } \\
\text { Penting }\end{array}$ & $\begin{array}{l}\text { Kurang } \\
\text { Penting }\end{array}$ & Penting & $\begin{array}{l}\text { Sangat } \\
\text { Penting }\end{array}$ & $\begin{array}{c}0 \\
0 \\
1 \\
33\end{array}$ & $\begin{array}{c}0 \\
0 \\
2,94 \\
97,06\end{array}$ \\
\hline Total & & & & & 34 & 100 \\
\hline $\begin{array}{l}\text { Konsumsi yang } \\
\text { diberikan selama } \\
\text { abdimas ibm ditempat } \\
\text { ini }\end{array}$ & $\begin{array}{l}\text { Tidak } \\
\text { Penting }\end{array}$ & $\begin{array}{l}\text { Kurang } \\
\text { Penting }\end{array}$ & Penting & $\begin{array}{l}\text { Sangat } \\
\text { Penting }\end{array}$ & $\begin{array}{c}0 \\
0 \\
2 \\
12\end{array}$ & $\begin{array}{l}0 \\
0 \\
90 \\
10\end{array}$ \\
\hline Total & & & & & 34 & 100 \\
\hline
\end{tabular}

Secara keseluruhan, feed back anggota kelompok home industri jamu tradisional madura terhadap pemateri dapat disampaikan sangat baik.Hal ini dapat tercapai karena pemateri yang kompeten dengan materi-materi pelatihan selama dilaksanakan IbM.
Berdasarkan tabel diatas dapat diketahui bahwa sebanyak 33 orang anggota kelompok home industri jamu tradisional Madura sebesar 90\% menyatakan bahwa ruang dan tempat yang dipergunakan nyaman dan sisanya 1 orang atau $10 \%$ juga menyatakan sangat penting terhadap ruang dan tempat yang dipergunakan. Tabel tsb juga menunjukkan bahwa sebanyak 12 orang atau sebesar $4,86 \%$ menyatakan puas terhadap konsumsi yang diberikan selama pelaksanaan program IbM dan sisanya 2 orang atau sebesar $4,88 \%$ menyatakan sangat puas terhadap konsumsi yang diberikan selama program IbM.

Secara umum, umpan balik terhadap ruangan dan tempat yang dipergunakan dan konsumsi yang disajikan dalam pelaksanaan program IbM dapat disimpulkan memuaskan. Hal ini didasarkan bahwa tempat dan akomodasi merupakan salah satu indikator yang dapat mendukung lancarnya pelaksanaan IbM ini. Sehingga dalam pelaksanaan kegiatan dipandang perlu meningkatkan kualitas tempat dan konsumsi selama pelaksanaan program kegiatan IbM.

Umpan balik terhadap pemberian ekomendasi terhadap kegiatan pelaksanaan IbM dapat dilihat pada tabel 6 . Tabel 6 menyajikan bahwa 22 orang anggota kelompok home industri atau sebesar 65\%. Direkomendasi kegiatan program IbM ini dan sisanya sebanyak 12 orang atau sebesar $35 \%$ sangat direkomendasi terhadap program IbM ini.

Tabel 7. Umpan balik terhadap Pemberian Rekomendasi

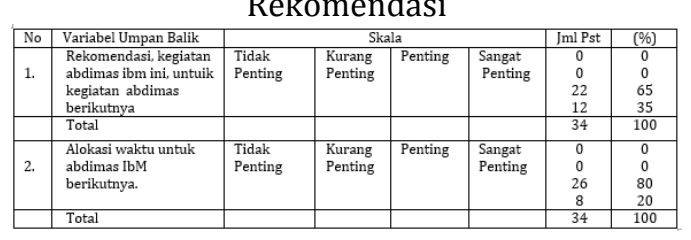

Tabel 7. Menunjukkan bahwa anggota kelompok home industri jamu tradisional menyatakan alokasi waktu untuk kegiatan Ibm adalah cukup bahkan perlu ditambah, yaitu sebanyak 26 orang atau sebesar $80 \%$ menyatakan alokasi waktu untuk kegiatan IbM adalah cukup.Sedangkan sisanya sebanyak 8 orang atau sebesar $20 \%$ menyatakan alokasi untuk kegiatan Ibm perlu ditingkatkan.

Kalau kita simpulkan umpanbalik terhadap rekomendasi sangat penting. Hal ini ditunjukkan bahwa sebagian besar anggota kelompok home industri jamu tradisional menyatakan alokasi waktu untuk kegiatan Ibm sedang bahkan perlu ditingkatkan. Sehingga hal ini menjadi dasar bagi mereka untuk home 
industri tsb. Serta hal ini juga menunjukkan antusias yang sangat tinggi dari kelompok home industri jamu terhadap pelaksanaan program IbM. Bahkan sebagian besar anggota kelompok home industri jamu menyarankan agar program kegiatan program Ibm ini dapat secara kontinyu dilaksanakan, mereka sangat butuh adanya pelatihan-elatihan yang dilaksanakan dalam program IbM.

\section{Permasalahan 6,}

Dalama pencapaian program IbM yang dilaksanakan ada kegaiatan yang bersifat transfer teknologi budidaya tanaman obat Pelatihan teknologi budidaya tanaman obatobatan sesuai dengan standar good agricultural practice (GAP). Untuk meningkatkan kualitas dan kuantitas bahan baku yang dipakai sebagai jamu tradisonal.Pelatihan ini dilakukan selama 1 minggu untuk setiap mitra. Dengan menyesuaikan materi pelatihan sesuai dengan potensi sumberdaya alam dan kondisi masyarakat.Desa Seddur dan Desa Klompang Timur mempunyai potensi hasil pertanian yang melimpah pada hampir setiap bulan tertentu yang menyebabkan mudah untuk memperoleh bahan baku obat-obatan keluarga. Dari hasil pelatihan rata-rata peserta mendapatkan $75 \%$ merasa Sangat puas. Sedang sisanya 25\% merasa Puas. Dari kesimpulan adanya pelatihan teknologi budidaya diharapkan dapat menguntungkan para petani cabe jamu yang ada di wilayah Kabupaten Pamekasan, Sehingga stock bahan baku jamu tradisional Madura tetap berlangsung sesuai standart Good Agricultural Practice (GAP).

\section{Kesimpulan}

\section{KESIMPULAN DAN SARAN}

Berdasarkan hasil pelaksanaan IbM bagi kelompok home industri jamu tradisional, dapat disimpulkan beberapa hal sebagai berikut:

a. Dengan adanya program IbM bagi kelompok home industri Jamu tradisional di Kec.Pakong telah mampu membentuk/mengembangkan perekonomian secara mandiri;

b. IbM telah mampu meningkatkan keterampilan berfikir kreatif untuk mengembangkan sumberdaya alam yang melimpah sebuah produk yang unggul dan bernilai ekonomis tinggi;

c. Luaran IbM berupa produk jamu khas masyarakat Madura dan produk yang berkhasiat;

d. Luaran IbM berupa produk berupa web ecommerce dan luaran berupa jasa adalah
Metode atau cara mengajar para masyarakat.

\section{Saran}

a. Perlu dikembangkan untuk desa pertanian yang tersebar di Kabupaten Pamekasan;

b. IbM untuk para pemuka agama, Karangtaruna, tokoh masyarakat, menjadikan mereka pengusaha yang mandiri dan memiliki wawasan intrepreneurship.

\section{DAFTAR PUSTAKA}

(1) Afriastini, JJ. Madjo Indo, ABD. 1989. Bertanam Jahe. Jakarta : Penebar Swadaya

(2) Afiastini, JJ. 1989. Daftar Nama Tanaman.Jakarta : Penebar Swadaya.

(3) Berg,A.A.Hyman Van Der, terjemahan Thomas Sumampouw, Sebab-Sebab Dan Gejala Umum Penyakit, Jakarta, Properous.

(4) Ds.Soewito.M, Memnafaatkan Pekarangan, Jakarta - C.V. Titik Terang.

(5) Effendi, Samsoeri. Ensiklopedi TumbuhTumbuhan, Surabaya, Karya Anda.

(6) Herstyani, F. 1988. "Mengenal Tanaman Adas". Dalam Majalah Trubus No. 223, Juni 1988. Jakarta : Yayasan Sosial Tani Membangun.

(7) LIPI LBN. 1980. Tumbuhan Obat. Jakarta : PN. Balai Pustaka.

(8) Mulyadi, Drs. 1988. "Aneka Khasiat Temu Lawak". Dalam Majalah Trubus No. 222, Mei 1988. Jakarta: Yayasan Sosial Tani Membangun.

(9) Murdiati, Ny. 1989. 200 Resep Jamu Jawa. Surabaya : CV. Amin

(10) Natawidjaja, P. Suparman, Apotek Hijau Dan Kesehatan, Jakarta, Pustaka Dian.

(11) Rifai,M.A. Kode International Tatanama TumbuhTumbuhan, Bogor, Herbariu Bogoriense.

(12) Sarwono, B. 1982. Jeruk Nipis dan Pemanfaatannya. Jakarta : Penebar Swadaya.

(13) Soemardjo-Sju, Resep Obat-Obatan Tradisional (Jamu Jawa), Surabaya, Karya Anda.

(14) Soeseno, Slamet. 1991. "Daun Dewa Melawan Tumor". Dalam Majalah Trubus No. 265; Desember 1991. Jakarta : Yayasan Sosial Tani Membangun.

(15) - - -. 1991. "Daun Tapak Dara untuk Diabetes". Dalam Majalah Trubus No. 263, Oktober 1991. Jakarta : Yayasan Sosial Tani Membangun.

(16) - - -. 1991. "Daun Tapak Liman sebagai Antiseptik". Dalam Majalah Trubus No. 259, Juni 1991. Jakarta : Yayasan Sosial Tani Membangun.

(17) Sw. Pringgohusodo, Jamu-Jamu Dari Madura, Yogyakarta, C.V. Nur Cahaya.

(18) Pohan, H.G. dan N.T. Antara. 2001. Pengaruh penambahan madu dan asam sitrat terhadap 
(19) karakteristik minuman fungsional dari sari buah mengkudu. Forum Komunikasi IHP (4): 11-20.

(20) Sudiarto, M. Rizal, M. Rahardjo, E. Djauhariya, Rudi T.S., Ma'mun, H Nurhayati, M. Sukmasari dan S. Nursamsiah, 2003. Penyiapan Teknologi Bahan Tanaman, Perbanyakkan, Standarisasi Bahan Baku dan Formulasi Anti Diabet Mengkudu. Laporan akhir hasil penelitian. Bagian Proyek Pengkajian Teknologi Partisipatif. Balittro. Badan Litbang Pertanian. Deptan : 1 - 52.

(21) Wijayakusuma, H.M., H.S. Dalimarta, A.S. Wirian, T. Yaputra, dan B. Wibowo. 1992. Tanaman berkhasiat obat di Indonesia. IV : 109 - 112

(22) Waha, L.G. 2001. Sehat dengan mengkudu. MSF Group, Jakarta. hal. 1 - 44. 